\title{
YIELD, BIOMASS PRODUCTION AND NUTRIENTS ACCUMULATION OF SUPER EARLY GENOTYPE OF COMMON BEAN
}

Adriano Stephan Nascente, Maria da Conceição Santana Carvalho

Embrapa Arroz e Feijão, Santo Antônio de Goiás, GO. Email: adriano.nascente@embrapa.br

\begin{abstract}
This work aimed to study the biomass production and nutrient uptake during plant development and nutrients exported by the grains of a super early genotype (SEG) of common bean. The irrigated field experiment was done during the 2016 growing season (winter season), under no-tillage system conditions, in the Cerrado region. Experimental design was in complete randomized block in split plots scheme, with four replications. Main plots comprised SEG of common bean (Colibri - control cultivar and CNFC 15874) and subplots were nine times of plant collection (14, 21, 28, 35, 42, 49, 56, 63 and 70 days after plant sowing, DAS) with separation in leaves, stem and pods. Absorption of nutrients by the shoots of SEG CNFC 15874 follows the decreasing order $\mathrm{N}>\mathrm{K}>\mathrm{Ca}>\mathrm{Mg}>\mathrm{P}>\mathrm{S}>\mathrm{Fe}>\mathrm{Zn}>\mathrm{Mn}>\mathrm{Cu}$. The maximum accumulation of nutrients in the leaves and stem of the SEG was at 42 DAS (full flowering stage) and in the pods was between 63 to 70 DAS (physiological maturation). Nitrogen, K, P, Ca, S, Fe, $\mathrm{Zn}, \mathrm{Mn}$ and $\mathrm{Cu}$ was the order of accumulated nutrients in grains of super early genotypes. Nitrogen, $\mathrm{P}$ and $\mathrm{Cu}$ was the nutrients with higher amount in the grains of SEG. IPR Colibri had higher number of pods, mass of grains, total and pods biomass production, nutrients accumulation and grain yield than CNFC 15874. Nutrients should be available to SEG of common bean between 14-21 DAS (third trifoliolate leaf).
\end{abstract}

Keywords: Phaseolus vulgaris; growth analysis; nutrient content; nutrient uptake; brazilian cerrado; sustainable agriculture.

\section{PRODUTIVIDADE, PRODUÇÃO DE BIOMASSA E ACÚMULO DE NUTRIENTES DE GENÓTIPOS SUPERPRECOCES DE FEIJÃO-COMUM}

\section{RESUMO}

Este trabalho teve como objetivo estudar a produção de biomassa e a absorção de nutrientes durante o desenvolvimento de plantas e nutrientes exportados pelos grãos de um genótipo superprecoce (GSP) de feijãocomum. O experimento irrigado de campo foi feito na safra de 2016 (inverno), sob plantio direto, na região do Cerrado. $O$ delineamento experimental foi em blocos completos ao acaso, em esquema de parcelas subdivididas, com três repetições. As parcelas foram compostas por GSP de feijão-comum (Colibri testemunha e CNFC 15874) e as subparcelas pelas épocas de amostragem de plantas $(14,21,28,35,42,49,56$, 63 e 70 dias após a semeadura das plantas, DAS) com separação em folhas, hastes e vagens. A absorção de nutrientes pela parte aérea do genótipo super precoce CNFC 15874 de feijão comum segue a ordem decrescente $\mathrm{N}>\mathrm{K}>\mathrm{Ca}>\mathrm{Mg}>\mathrm{P}>\mathrm{S}>\mathrm{Fe}>\mathrm{Zn}>\mathrm{Mn}>\mathrm{Cu}$. O acúmulo máximo de nutrientes nas folhas e caule dos GSP foi aos 42 DAS (florescimento pleno) e nas vagens foi entre 63 a 70 DAS (maturação fisiológica).

Nitrogênio, K, P, Ca, S, Fe, Zn, Mn e Cu foi a ordem dos nutrientes acumulados em grãos de GSP. Nitrogênio, P e Cu foram os nutrientes com maior quantidade nos grãos de GSP. IPR Colibri teve maior número de vagens, massa de grãos, produção de biomassa total e de vagens, acúmulo de nutrientes e produtividade de grãos do que CNFC 15874. Nutrientes devem estar disponíveis para GSP de feijão comum entre 14-21 DAS (terceira folha trifoliolada).

Palavras-chave: Phaseolus vulgaris; análise de crescimento; teor de nutrientes; absorção de nutrientes; cerrado brasileiro. 


\section{INTRODUCTION}

The common bean (Phaseolus vulgaris L.) crop has a great economic importance for people in Latin America and Eastern and Southern Africa, which use the grain of this crop in their daily human diets (ROSALES-SERNA et al., 2004; LIMA et al., 2005). In Brazil, this crop is produced in three seasons, called the wet or summer season, off season and winter season (NASCENTE et al., 2016; 2012). In 2016 winter season in the South Central region (Midwest and Southeast), this crop was grown on 172,400 ha with a production of 433,600 $\mathrm{Mg}$ of grain, accounting for $13.2 \%$ of the total common bean grain production in Brazil (CONAB, 2017). This data shows the importance of this growing season for price and production stability in the Brazilian agricultural market.

Mainly in the winter season, farmers are eager to have varieties with shorter life cycle to allow for the cultivation of three crops in the same area during the year (NASCENTE; MELO, 2015). Besides, genotypes that allow achieving high grain yields in shortest time would provide water irrigation and power savings and hence reduce the cost of production (NASCENTE et al., 2016).

Lately, it was developed in Brazil super early genotypes (SEG) of common bean (NASCENTE; MELO, 2015). These SEGs have life cycles of 65-75 days, while traditional cultivars have life cycles of 95-105 days (NASCENTE; MELO, 2015). These are new materials and no studies have been performed under field conditions about their performance. However, in order to develop a management system that fully allows exploiting genetic potential of these SEGs of common bean, they have to be characterized in more detail.

The determination of nutrient absorption capacity during the crop development phases would allow evaluating when they are more necessary to the plants (AUGOSTINHO et al., 2008). Besides, determination of dry biomass accumulation by plant and its parts: stems, leaves, and pods (growth analyze) and nutrients accumulation in each part, would help to understand where these nutrients are more important during plant development (ROSALESSERNA et al., 2004; ANDRADE et al., 2009; SANTOS et al., 2015). This growth analyze can be used to verify the effects of the management system and yield potential on different genotypes (FALQUETO et al., 2009; ALVAREZ et al., 2012).

According to Fageria et al. (2011), Pagani e Mallarino (2012) and Crusciol et al. (2013), the accumulation of nutrients by crop plants can be used as a nutrient extraction parameter from the soil for future fertilizing recommendation systems. Therefore, studies of absorption capacity nutrients during the plant development phases of common bean can be used as an important tool for fertilization definition, once we could define quantity demanded in each period of plant development (HAAG et al., 1967; SORATTO et al., 2013; PEGORARO et al., 2014).

Vieira et al. (2009) observed that maximum accumulation of biomass dry matter by the traditional (life cycle around 90-100 days) common bean cultivar Talismã occurred at 48 days after emergence, indicating that the management of fertilization should be held before this time. For SEGs of common bean that have shorter life cycle, fertilization should be done earlier than this found in Talismã. We had the hypothesis that the study of nutrients uptake during plant development in super early genotypes of common bean will allow understanding when these nutrients are more demanded by the plants. Thus, this work aimed to study the biomass production and nutrient uptake during plant development and nutrients exported by the grains of a super early genotype of common bean.

\section{MATERIALS AND METHODS}

The irrigated field experiments were conducted in the 2016 winter growing season at Capivara Farm, located in the city of Santo Antonio de Goias, GO, Central Region of Brazil. The geographical coordinates of the site are $16^{\circ} 28^{\prime} 00^{\prime \prime}$ $S$, 490 17' 00" West. The altitude of the site is 823 $\mathrm{m}$. The climate is tropical savanna and is considered Aw according to its Köppen classification (ALVARES et al., 2014). There are two well-defined seasons: usually, the dry season extends from May to September (autumn/winter) and the wet season from October to April (spring/summer).

The soil was classified as a clay loam (kaolinitic, thermic Typic Haplorthox) acidic soil (EMBRAPA, 2006). Prior to the experiment, the chemical characteristics of the soil were 
determined (Table 1). The soil analysis was

performed according to Donagema et al. (2011).

Table 1. Chemical soil attributes from the experimental area before the beginning of the trials. Santo Antônio de Goiás, Goiás, Brazil, growing season winter 2016.

\begin{tabular}{|c|c|c|c|c|c|c|}
\hline Layer & $\mathrm{pH}$ & $\mathrm{Ca}$ & $\mathrm{Mg}$ & $\mathrm{Al}$ & $\mathrm{H}+\mathrm{Al}$ & SOM \\
\hline $\mathrm{cm}$ & in $\mathrm{H}_{2} \mathrm{O}$ & \multicolumn{4}{|c|}{ 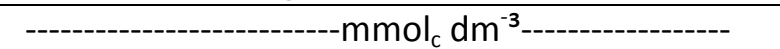 } & $\mathrm{g} \mathrm{kg}^{-1}$ \\
\hline $0-5$ & 4.8 & 17.4 & 10.5 & 1.0 & 38.0 & 36.34 \\
\hline 5 a 10 & 4.6 & 11.3 & 6.8 & 2.0 & 37.0 & 30.38 \\
\hline 10 a 20 & 4.4 & 7.1 & 4.6 & 4.0 & 35.0 & 27.81 \\
\hline Layer & $\mathrm{P}$ & $\mathrm{K}$ & $\mathrm{Cu}$ & $\mathrm{Zn}$ & $\mathrm{Fe}$ & $\mathrm{Mn}$ \\
\hline $\mathrm{cm}$ & \multicolumn{6}{|c|}{ 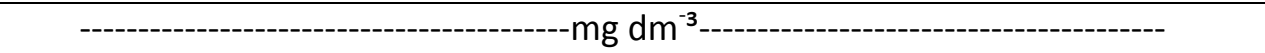 } \\
\hline $0-5$ & 24.9 & 134 & 1.9 & 12.4 & 6.9 & 22.7 \\
\hline 5 a 10 & 56.8 & 86 & 2.6 & 13.8 & 8.8 & 16.0 \\
\hline 10 a 20 & 20.2 & 42 & 2.6 & 7.7 & 6.7 & 12.0 \\
\hline
\end{tabular}

$\S$ SOM - soil organic matter.

The experimental area has been cultivated in a no-tillage system (NTS) for seven consecutive years. The last crop rotations were soybean (spring/summer), followed by corn - Zea mays L. (summer), and our trial. The dry biomass of corn on the soil surface at common bean sowing was $10 \mathrm{Mg}$ $\mathrm{ha}^{-1}$.

Regarding yield components, grain yield and nutrients exported by the grains, the experimental design was a randomized complete blocks layout with two treatments and sixteen replications. Treatment comprised the dry bean genotypes (Colibri - control and CNFC 15874). For the biomass production and nutrient accumulation, experimental design was a randomized complete blocks arranged with a split plot scheme, with four replications. Main plots comprised the dry bean genotypes (Colibri - control and CNFC 15874, will be released as a new cultivar), sub plots were nine times periods of plant collection [14 (end of $V_{3}$ stage), 21 (end of $V_{4}$ stage)], 28 (pre flowering stage), 35 (full flowering stage), 42 (early pod formation), 49 (pod formation), 56 (grain filling), 63 (grain filling) and 70 days (physiological maturation) after plant sowing) with separation in leaves, stem and pods. The plots consisted of 10 eight-meter-long rows, spaced $0.45 \mathrm{~m}$ apart. The usable area of each plot was formed by the six central meters of the two central rows, where we evaluate the yield components and grain yield.

Approximately 15 days before sowing, the experimental area was desiccated with glyphosate $+2,4 \mathrm{D}$. The base fertilization, to be applied in the sowing furrows, was calculated according to the soil's chemical characteristics and the recommendations of Sousa and Lobato (2004). The fertilizer applied at sowing consisted of $60 \mathrm{~kg} \mathrm{ha}^{-1}$ of $\mathrm{P}_{2} \mathrm{O}_{5}$ (simple superphosphate) and $45 \mathrm{~kg} \mathrm{ha}^{-1}$ of $\mathrm{N}$ (urea). Topdressing fertilization was performed at the $V_{4}$ phenological stage (third trifoliate leaf) with $45 \mathrm{~kg} \mathrm{ha}^{-1}$ of $\mathrm{N}$ (urea).

The sowing of common bean genotypes was mechanically performed with a no-till seeding (Semeato, model Personale Drill 13, Passo Fundo, RS, Brazil) on June $1^{\text {st }}, 2016$ in a $0.45 \mathrm{~m}$ row spacing and with 15 seeds per meter. Cultural practices were performed according to the recommendations for the crop to keep the area free of weeds, diseases, and insects. A central pivot irrigation system was used and in the management of water, the methods recommended by Doorenbos and Pruitt (1976) were used.

Seedling emergence occurred at six days after sowing. The average of $V_{4}$ stages were reached at 17 days after sowing (DAS). The average of the full flowering stage was at 35 DAS. The average growing season (length of time from emergence to harvest) was 70 DAS (August, $9^{\text {th }}$ 2016).

Samples were collected at $14,21,28,35,42$, $49,56,63$ and 70 DAS outside of the usable area. In each experimental unit, plants contained in $1.0 \mathrm{~m}$ rows, out of the usable area, were collected. From all collected plants, we separated the leaves, stems, and pods with grains, and the roots were discarded. These plant structures were dried at $60^{\circ} \mathrm{C}$ in a forced air circulation oven until a constant mass was achieved. We calculated the production 
of dry biomass of each plant structure and total (leaves + stems + pods with grains).

After drying, leaves, stems and pods were ground separately and the samples were analyzed for chemical composition. The concentrations of $\mathrm{N}$, $\mathrm{P}, \mathrm{K}, \mathrm{Ca}, \mathrm{Mg}, \mathrm{S}, \mathrm{Cu}, \mathrm{Fe}, \mathrm{Zn}$ and $\mathrm{Mn}$ were determined using the methods described by Malavolta et al. (1997). Nitrogen was extracted with $\mathrm{H}_{2} \mathrm{SO}_{4}$, and the other nutrients were extracted with a nitroperchloric solution. The $\mathrm{N}$ concentration in the digested solution was determined by Kjeldahl analysis. The $\mathrm{P}, \mathrm{K}, \mathrm{Ca}, \mathrm{Mg}, \mathrm{S}, \mathrm{Cu}, \mathrm{Fe}, \mathrm{Zn}$ and $\mathrm{Mn}$ concentrations were determined by atomic absorption spectrophotometry. The accumulation of each nutrient in each plant structure was calculated by multiplying the biomass production of leaves, stems and pods with grains by the content of the nutrient.

The harvested common bean seeds were weighed and the yield expressed as $130 \mathrm{~g} \mathrm{~kg}^{-1}$. In addition, the following yield components were assessed in the usable area: the number of pods per plant and number of seeds per pod (evaluated in 10 plants per plot that were chosen at random), and the weight of 100 seeds (calculated from eight random samples per plot). In each plot, one sample of $100 \mathrm{~g}$ of grains was taken for nutrient analyses. The grains were ground and analyzed to determine the levels of nutrients $(\mathrm{P}, \mathrm{K}, \mathrm{Ca}, \mathrm{Mg}, \mathrm{S}, \mathrm{Cu}, \mathrm{Fe}, \mathrm{Zn}$ and $\mathrm{Mn}$ ) according to the methodology proposed by Malavolta et al. (1997). The grain yield was multiplied by the nutrient content to calculate the amount of nutrients exported by the common bean grains.

An analysis of variance and $F$ test were performed for all variables. The analysis of variance was performed considering the effects of genotypes and evaluation time. From the significant data we performed the LSD test at $p$ $<0.05$. These analyses were performed using SAS statistical software (SAS, 1999). Data of biomass accumulation and nutrient accumulation in the plant and in different structures during the common bean life cycle were fitted to non-linear regression models Sigmoid and Gaussian with three parameters (PEGORARO et al., 2014) by using the software Sigma Plot ${ }^{\circledR}$, version 11.2.

\section{RESULTS AND DISCUSSION}

\section{Biomass and nutrients translocation}

It was found that until 14 days after common bean sowing, there was a slow growing of the plants from both genotypes (Figure 1). After 14 DAS, plant development for both genotypes, grown up very fast until harvesting. Total plant biomass of CNFC 15874 grown from $47.24 \mathrm{~kg} \mathrm{ha}^{-1}$ at 14 DAS to $191.04 \mathrm{~kg} \mathrm{ha}^{-1}$ at $21 \mathrm{DAS}$, IPR Colibri grown from $42.95 \mathrm{~kg} \mathrm{ha}^{-1}$ at 14 DAS to $165.42 \mathrm{~kg} \mathrm{ha}^{-1}$ at 21 DAS. This period was the beginning of plant development, $\mathrm{V}_{4}$ stage (third trifoliolate stage) was at 17 DAS. From this stage until next development stage at 28 DAS, $R_{5}$ stage (pre flowering stage), plant has a very fast development and produce more than 20 trifoliolate leaves (ANDRADE et al., 2009). Growing fast from $V_{4}$ stage to $R_{5}$ stage is not a novelty in common bean, however, we could see that in SEG it reached at 17 DAS and in Perola it is about 25 to 30 DAS (SORATTO et al., 2013; PEGORARO et al., 2014). The estimative of IP (inflexion point), which means the DAS where the daily accumulation rate is maximum, was at 41 DAS for stems and at 34 DAS for leaves to CNFC 15874 and 39 DAS for stems and 29 DAS for leaves in IPR Colibri. Pegoraro et al. (2014) using cv. Pérola observed low biomass production until 25-30 DAS. Vieira et al. (2009), evaluating accumulation of dry biomass of common bean cvs. Ouro Negro and BRS MG Talismã (traditional cultivars), reported slight increases in dry matter accumulation up to 28 and 30 DAS, respectively. Gomes (2000) added that the period in which there are larger increases in accumulation of dry matter from common bean plant varies between 40 and $70-80$ DAS. These data of other researches showed that traditional cultivars (Pérola and Jalo) have accumulated biomass later (in days) than super-early genotypes. This could be because super early genotypes of common bean has shorter life cycle (NASCENTE; MELO, 2015). In our data, CNFC 15874 had the highest daily accumulation of dry matter at 52 DAS.

In relation to the growth of organs present in common bean shoots, it was observed that leaves and stems accounting for $100 \%$ of the relative accumulation of biomass of the common bean until the 42 DAS (Figure 1), mainly leaves that represented around 63\% for CNFC 15874 and 68\% for IPR Colibri. After this period, with the beginning of the reproductive stage and until the end of 
cultivation, at 70 DAS, the relative accumulation of leaves and stems was reduced to less than $33 \%$ in the CNFC15874 and 20\% in Colibri. On the other hand, biomass production of pods with grains was $42 \%$ in the CNFC 15874 and 58\% in Colibri. In this sense, we can infer that Colibri was more efficient in convert biomass from leaves and stems to pods with grains than CNFC 15874. Highest daily accumulation of pods + grains was at 61.08 DAS for CNFC 15874 and 61.31 DAS for IPR Colibri (Figure $1)$.

Figure 1. Biomass production and relative accumulation of biomass by leaves, stems, pods and total of super early genotypes of common bean during the crop life cycle. Growing season 2016.

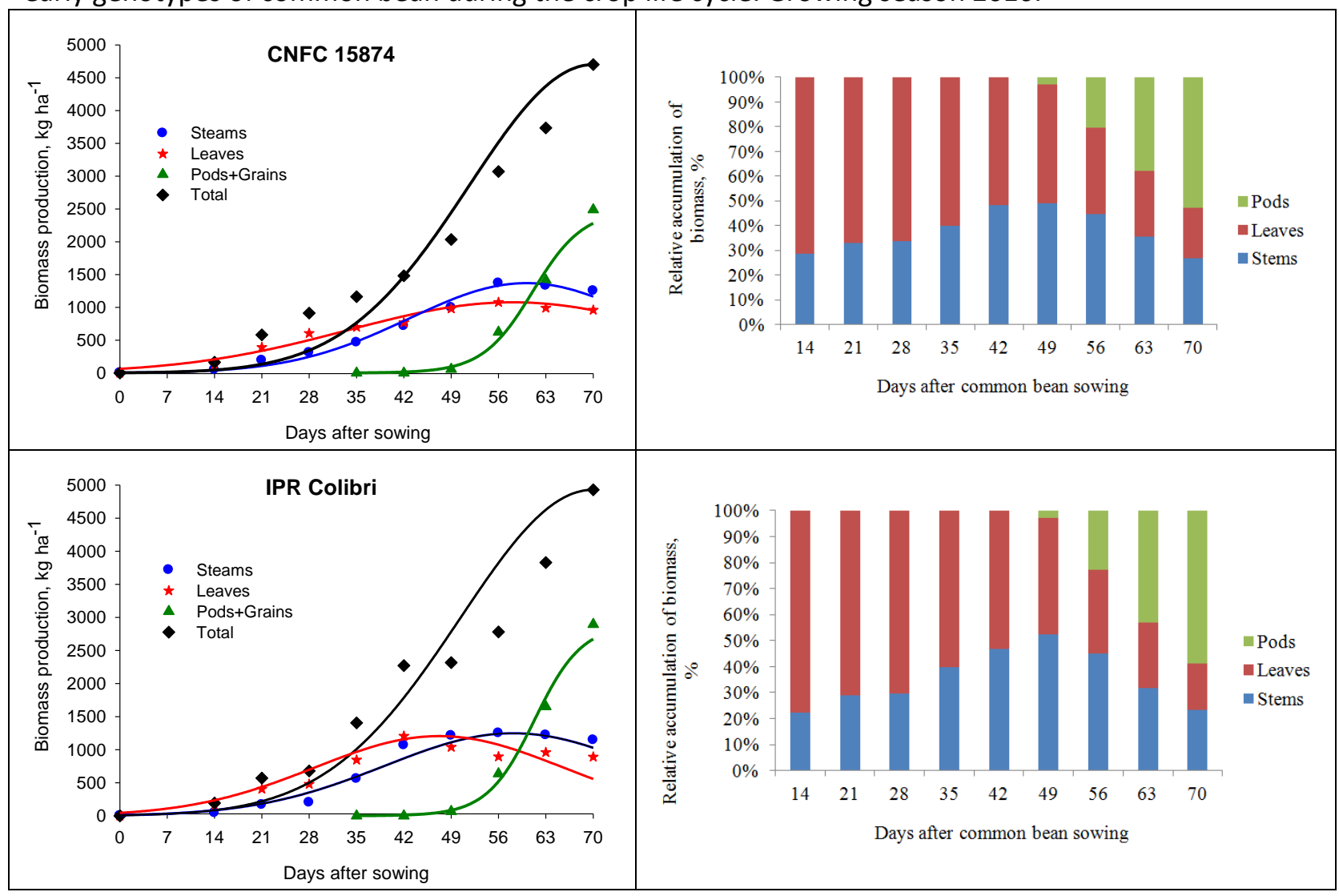

These data (Figure 1) indicated the high level of exportation biomass via grains and the massive contribution of leaves and stems in the translocation of photoassimilates for the growth of reproductive organs of the common bean. Gomes (2000) observed that the greater accumulation of organic matter occurs in the leaves and stems and later on pods. Besides, the maximum IP in the leaves occurred between 27 to 41 DAS and in the stems between 35 and 51 DAS, which coincide to full flowering stage and beginning of pod formation. It reinforce that full flowering is the best stage for leaf sampling in order to evaluate the nutritional status of these genotypes. This indicate that, after this period nutrient accumulation in leaves and stems, these nutrients seems to be reallocated to pods, once reduced its values in leaves and stems and increased in pods (Figures 25). Corroborating this information, Wien et al. (1976) added that in phases of pod formation and grain filling about $45 \%$ of the leaves and stem assimilates are translocated to the seeds. 
Figure 2. Accumulation of $\mathrm{N}, \mathrm{P}, \mathrm{K}, \mathrm{Ca}, \mathrm{Mg}$ and $\mathrm{S}$ by leaves, stems, pods and total of super early genotypes CNFC 15874 of common bean during the crop life cycle. Growing season 2016.

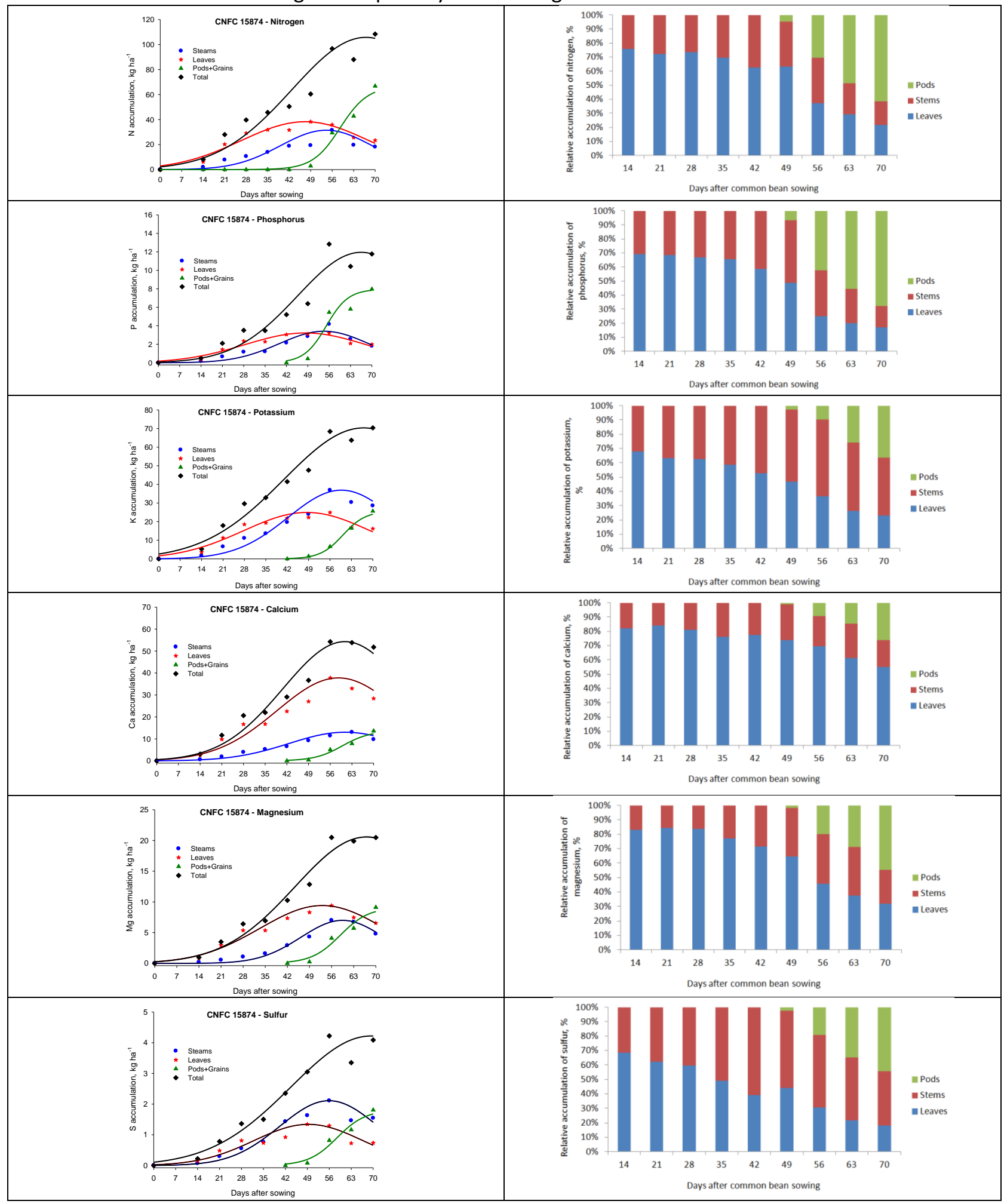


Figure 3. Accumulation of $\mathrm{Cu}, \mathrm{Fe}, \mathrm{Mn}$ and $\mathrm{Zn}$ by leaves, stems, pods and total of super early genotype CNFC 15874 of common bean during the crop life cycle. Growing season 2016.

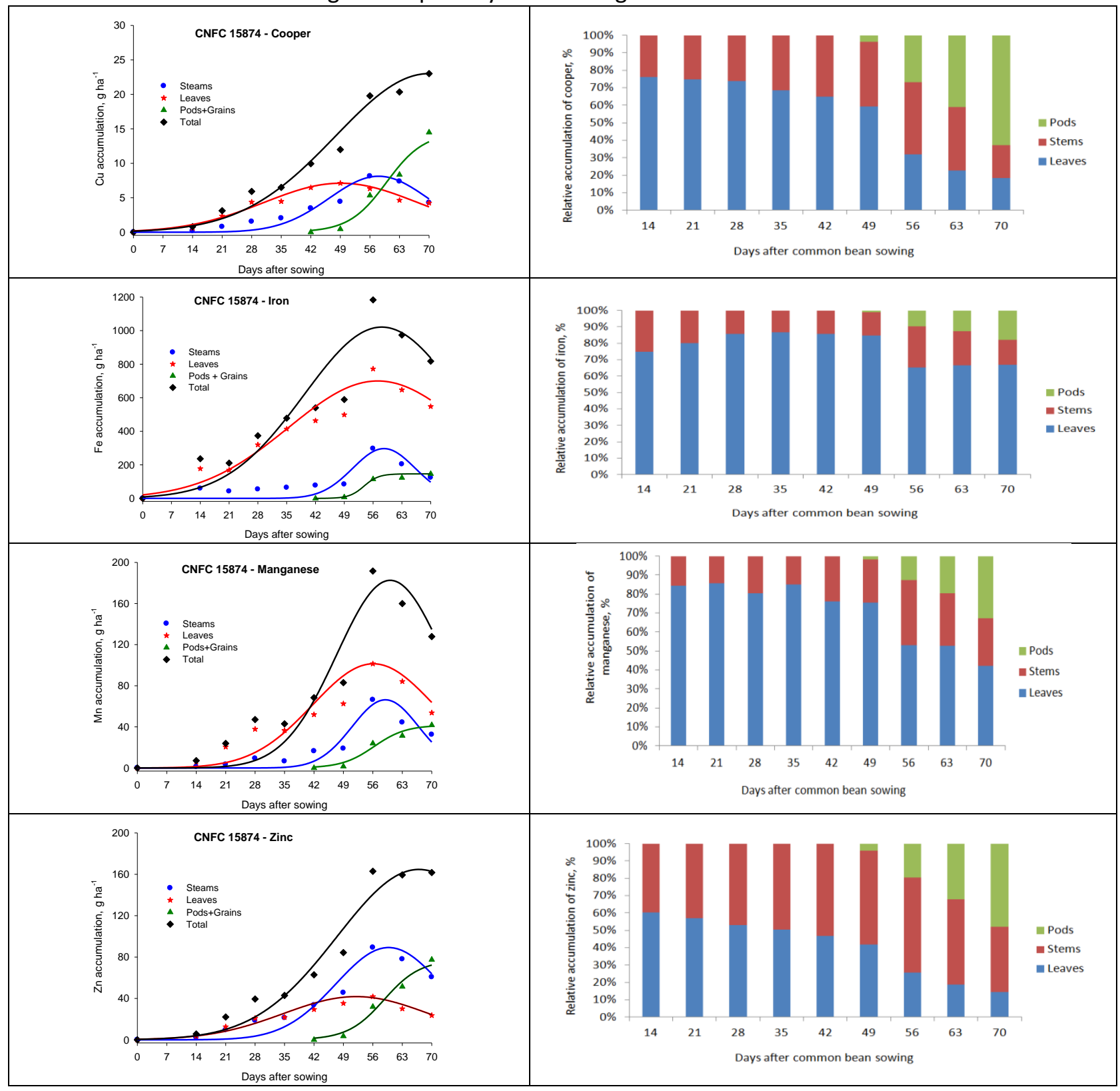


Figure 4. Accumulation of N, P, K, Ca, Mg and S by leaves, stems, pods and total of super early genotypes IPR Colibri of common bean during the crop life cycle. Growing season 2016.

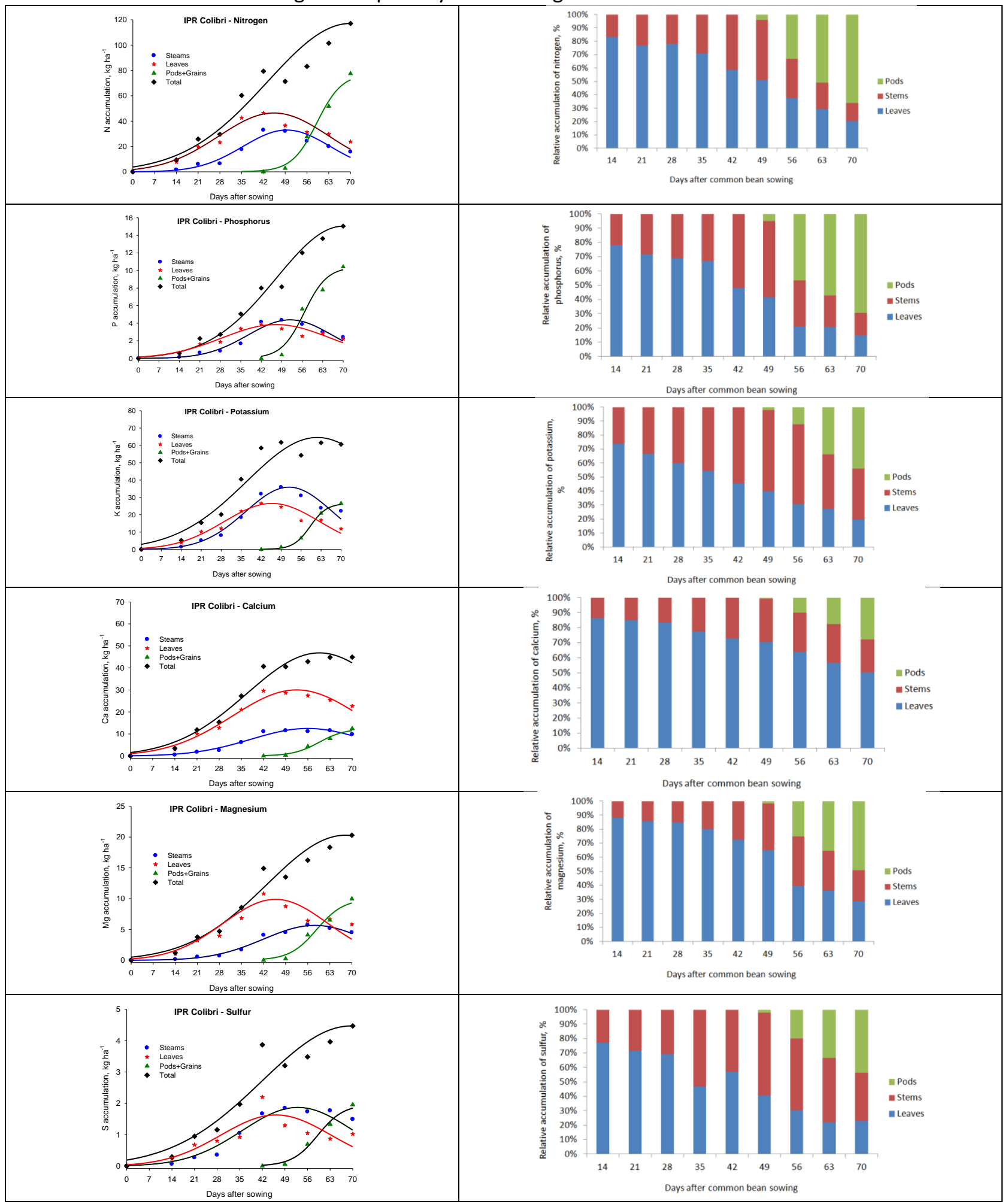


Figure 5. Accumulation of $\mathrm{Cu}, \mathrm{Fe}, \mathrm{Mn}$ and $\mathrm{Zn}$ by leaves, stems, pods and total of super early genotype IPR Colibri of common bean during the crop life cycle. Growing season 2016.

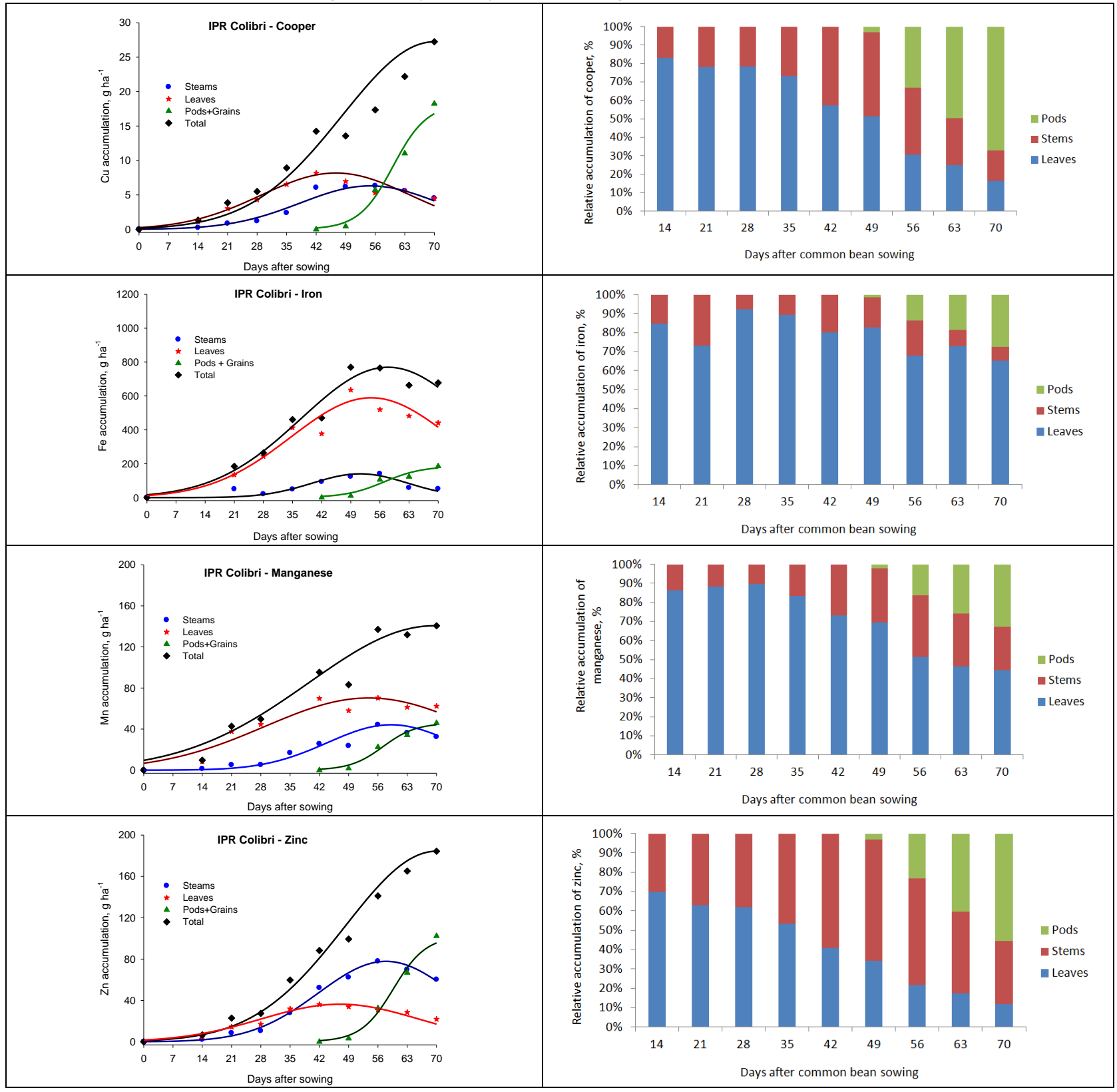

The maximum accumulation of nutrients $(\mathrm{N}$, $\mathrm{P}, \mathrm{K}, \mathrm{Ca}, \mathrm{Mg}, \mathrm{S}, \mathrm{Cu}, \mathrm{Fe}, \mathrm{Mn}$ and $\mathrm{Zn}$ ) in shoots of super-early genotypes was close to or in the physiological maturity phase around 63-70 DAS (Figures 2-5). The estimated amount of nutrients accumulated by common bean plants genotype Colibri followed the order $\mathrm{N}\left(117.08 \mathrm{~kg} \mathrm{ha}^{-1}\right)>\mathrm{K}$ $\left(64.75 \mathrm{~kg} \mathrm{ha}^{-1}\right)>\mathrm{Ca}\left(44.95 \mathrm{~kg} \mathrm{ha}^{-1}\right)>\mathrm{Mg}(20.30 \mathrm{~kg}$ $\left.\mathrm{ha}^{-1}\right)>\mathrm{P}\left(15.14 \mathrm{~kg} \mathrm{ha}^{-1}\right)>\mathrm{S}\left(4.47 \mathrm{~kg} \mathrm{ha}^{-1}\right)>\mathrm{Fe}$ $\left(769.43 \mathrm{~g} \mathrm{ha}^{-1}\right)>\mathrm{Mn}\left(140.62 \mathrm{~g} \mathrm{ha}^{-1}\right)>\mathrm{Zn}(184.35 \mathrm{~g}$ $\left.\mathrm{ha}^{-1}\right)>\mathrm{Cu}\left(27.44 \mathrm{~g} \mathrm{ha}^{-1}\right)$. In common bean plants genotype CNFC 15874 followed the order N (105.76 $\left.\mathrm{kg} \mathrm{ha}^{-1}\right)>\mathrm{K}\left(70.36 \mathrm{~kg} \mathrm{ha}^{-1}\right)>\mathrm{Ca}\left(54.30 \mathrm{~kg} \mathrm{ha}^{-1}\right)>\mathrm{Mg}$ $\left(20.61 \mathrm{~kg} \mathrm{ha}^{-1}\right)>\mathrm{P}\left(11.95 \mathrm{~kg} \mathrm{ha}^{-1}\right)>\mathrm{S}\left(4.22 \mathrm{~kg} \mathrm{ha}^{-1}\right)>$ Fe $\left(1021.10 \mathrm{~g} \mathrm{ha}^{-1}\right)>\mathrm{Mn}\left(182.56 \mathrm{~g} \mathrm{ha}^{-1}\right)>\mathrm{Zn}$ (164.70 $\left.\mathrm{g} \mathrm{ha}^{-1}\right)>\mathrm{Cu}\left(23.01 \mathrm{~g} \mathrm{ha}^{-1}\right)$ (Table 2). Although this result is for super-early genotype, this order of uptake is similar to that reported by Vieira et al. (2009) in conventional genotypes. Soratto et al. (2013) reported uptake by common bean shoots cultivar 'Pérola' of $140 \mathrm{~kg} \mathrm{ha}^{-1} \mathrm{~N}, 16.5$ $\mathrm{kg} \mathrm{ha}^{-1} \mathrm{P}, 120 \mathrm{~kg} \mathrm{ha}^{-1} \mathrm{~K}, 69 \mathrm{~kg} \mathrm{ha}^{-1} \mathrm{Ca}, 17.9 \mathrm{~kg} \mathrm{ha}^{-1}$ 
$\mathrm{Mg}$, and $16.3 \mathrm{~kg} \mathrm{ha}^{-1} \mathrm{~S}$ for a grain production of $3.657 \mathrm{~kg} \mathrm{ha}^{-1}$. According to Pegoraro et al. (2014), that also studied nutrients uptake by 'Perola' cultivar, common bean plant is known as a nutrient-absorbing plant until the end of the growing cycle, and we could see that even in the
SEG, which the life cycle is much lower than conventional genotypes, common bean plants uptake high amount of nutrients. Also Vieira et al. (2009) reported common bean traditional cultivars uptake nutrients until the end of crop cycle.

Table 2. Total nutrient extraction (leaves, stems and pods + grains) of shoots, nutrients exportation by grains and percentage of nutrient exportation by grains in relation to nutrients extracted (Exp/Ext) by plants of super early genotypes of common beans varieties. Santo Antônio de Goiás, growing season 2016. Grain yield of 2189 $\mathrm{kg} \mathrm{ha}^{-1}$ for CNFC 15874 and $2549 \mathrm{~kg} \mathrm{ha}^{-1}$ for IPR Colibri.

\begin{tabular}{|c|c|c|c|c|c|c|}
\hline \multirow{3}{*}{ Macronutrient } & \multicolumn{3}{|c|}{ IPR Colibri } & \multicolumn{3}{|c|}{ CNFC 15874} \\
\hline & Extraction & Exportation & Exp/Ext & Extraction & Exportation & Exp/Ext \\
\hline & \multicolumn{2}{|c|}{--------kg ha ${ }^{-1}--------$} & $\%$ & \multicolumn{2}{|c|}{--------kg ha'-1-------- } & $\%$ \\
\hline$N$ & 117.08 & 67.87 & 57.97 & 105.76 & 63.17 & 59.73 \\
\hline$P$ & 15.14 & 10.12 & 66.84 & 11.95 & 10.05 & 85.77 \\
\hline K & 64.75 & 31.32 & 48.37 & 70.36 & 31.51 & 44.78 \\
\hline $\mathrm{Ca}$ & 44.95 & 3.53 & 7.86 & 54.30 & 3.35 & 6.17 \\
\hline $\mathrm{Mg}$ & 20.30 & 4.07 & 20.05 & 20.61 & 4.47 & 21.69 \\
\hline $\mathrm{S}$ & 4.47 & 2.13 & 47.65 & 4.22 & 2.00 & 47.39 \\
\hline Micronutrient & \multicolumn{2}{|c|}{----------g ha'---------- } & $\%$ & \multicolumn{2}{|c|}{----------g ha ${ }^{-1}----------$} & $\%$ \\
\hline $\mathrm{Cu}$ & 27.23 & 14.54 & 53.40 & 23.01 & 17.16 & 74.58 \\
\hline $\mathrm{Fe}$ & 769.43 & 110.30 & 14.33 & 1021.10 & 122.38 & 11.99 \\
\hline $\mathrm{Mn}$ & 140.62 & 27.44 & 19.51 & 182.56 & 34.40 & 18.84 \\
\hline $\mathrm{Zn}$ & 184.35 & 77.17 & 41.86 & 164.70 & 89.13 & 54.12 \\
\hline
\end{tabular}

The uptake of nutrients by super early genotypes of common bean was directly linked to the accumulation of dry matter (Figures 1 to 5). So, in the early stages of plant growth there was a slow accumulation of nutrients from 0 to 14 DAS. From 14 to 42 DAS the increases in absorption of nutrients were accentuated, stabilizing from the physiological maturity until the end of the cycle. The period in which significant gains started in nutrient accumulation occurred from 14 to 21 DAS. For example, $\mathrm{N}$ content in common beans plants was $8.18 \mathrm{~kg} \mathrm{ha}^{-1}$ in genotype CNFC 15874 at 14 DAS and $28.08 \mathrm{~kg} \mathrm{ha}^{-1}$ at $21 \mathrm{DAS}$, an increasing of $342 \%$. In the genotype IPR Colibri, N was $9.34 \mathrm{~kg} \mathrm{ha}^{-1}$ at 14 DAS and $25.79 \mathrm{~kg} \mathrm{ha}^{-1}$ at 21 DAS. Potassium content varies from $5.27 \mathrm{~kg} \mathrm{ha}^{-1}$ (14 DAS) to $17.88 \mathrm{~kg} \mathrm{ha}^{-1}$ (21 DAS) for CNFC 15874 and from $5.22 \mathrm{~kg} \mathrm{ha}^{-1}$ (14 DAS) to $15.41 \mathrm{~kg} \mathrm{ha}^{-1}$ (21 DAS) for IPR Colibri. Calcium content varies from $3.05 \mathrm{~kg} \mathrm{ha}^{-1}$ (14 DAS) to $11.64 \mathrm{~kg} \mathrm{ha}^{-1}$ (21 DAS) for CNFC 15874 and from $3.47 \mathrm{~kg} \mathrm{ha}^{-1}$ (14 DAS) to $11.87 \mathrm{~kg} \mathrm{ha}^{-1}$ (21 DAS) for IPR Colibri. Thus, it is possible to state that nutrients should be available to super-early genotypes of common bean plants from 14 DAS, when increase the demand by nutrients from the plants due the fast growing from this period until full flowering stage.

In general, common bean fertilization at sowing is done with N-P-K and only N is done at topdressing at $\mathrm{V}_{4}$ stage (third trifoliolate leave) (ARAÚJO et al., 1996). According to our results, farmers should be aware that topdressing fertilization should be done very close to the sowing time (before 17 DAS) in order to make available nitrogen to the plants in the beginning of the fast growing. This time is much lower than in the conventional common bean cultivars. According to Pegoraro et al. (2014) the best time for $\mathrm{N}$ topdressing fertilization is before 35 DAS for 'Perola' cultivar. Besides, irrigated systems that yield potential is higher than $2.500-3.000 \mathrm{~kg} \mathrm{ha}^{-1}$, could have higher demand for potassium in the shoots up to 42 DAS, and would be also necessary to use potassium fertilization at topdressing. Nascente et al. (2012) achieved higher common bean grain yield when topdressing fertilization was done with $60 \mathrm{~kg} \mathrm{ha}^{-1}$ of $\mathrm{K}_{2} \mathrm{O}$ at $17 \mathrm{DAS}$. According to Lacerda et al. (2015) and Bergamin et al. (2008), 
when applying greater amount of potassium ( $>50$ $\mathrm{kg} \mathrm{ha}^{-1}$ of $\mathrm{K}_{2} \mathrm{O}$ ) as potassium chloride $(\mathrm{KCl})$ at sowing caused damage to the seed and radicle of plants. This topdressing fertilization with $\mathrm{K}$ should be done between 14 to 21 DAS for the super-early genotypes of common bean, or around the $V_{4}$ stage. Although the maximum IP of nutrients in the common bean shoots occurred between 36 and 48 DAS, depending on the nutrient, the accumulation continued until the end of the plant cycle $(68-70$ DAS). This indicates that there may be response to applications of some nutrients via foliar spraying in the reproductive phase, when root uptake is no longer efficient, due to the translocation of photoassimilates preferentially to the formation of pods and grain filling.

\section{Yield components and grain yield}

Number of pods per plant, mass of 100 grains and grain yield was affected by the genotypes evaluated (Table 3). IPR Colibri had higher values for all these variables, as grain yield is a function of yield components (ARAÚJO et al., 1996), the highest values of pods and mass of grains can explain the highest grain yield in the cultivar IPR Colibri instead of CNFC 15874. Besides, IPR Colibri had greater total and pods biomass (Figure 1), nutrients accumulation (Figures 2-5) and translocated more nutrients to the pods than CNFC 15874 (Figure 1). According to Fageria et al. (2011), plants with a greater absorption capacity of nutrients tend to be more productive.

Table 3. Number of pods per plant (NPP), number of grains per pod (NGP), mass of 100 grains (MASS) and grain yield (YIELD) of super early genotypes of common bean as a function of genotypes. Santo Antônio de Goiás, growing season 2016.

\begin{tabular}{lccccc}
\hline & \multirow{2}{*}{ Genotypes } & NPP & NGP & MASS & YIELD \\
\cline { 2 - 5 } & & Number & number & grams & $\mathrm{kg} \mathrm{ha}^{-1}$ \\
IPR Colibri & 15.13 & 4.55 & 18.13 & 2549 \\
CNFC 15874 & 13.00 & 4.28 & 15.16 & 2189 \\
\hline Factors & & \multicolumn{3}{c}{ Anova (F probability) } \\
Genotype (G) & 0.0271 & 0.0551 & 0.0425 & 0.0418 \\
\hline
\end{tabular}

\section{Nutrients accumulated and exported by the grains}

Data of accumulation of nutrients $\mathrm{N}, \mathrm{P}, \mathrm{K}, \mathrm{Ca}$, $\mathrm{Mg}, \mathrm{S}, \mathrm{Cu}, \mathrm{Fe}, \mathrm{Mn}$ and $\mathrm{Zn}$ in the grains was similar in the two genotypes studied (Table 3 ). Nitrogen was the nutrient most exported by the grain with values of $67.87 \mathrm{~kg} \mathrm{ha}^{-1}$ in IPR Colibri and $63.17 \mathrm{~kg} \mathrm{ha}^{-1}$ in CNFC 15874. Potassium (31.32 kg ha ${ }^{-1}$ in IPR Colibri and $31.51 \mathrm{~kg} \mathrm{ha}^{-1}$ in CNFC 15874) was the second and phosphorus (10.12 $\mathrm{kg} \mathrm{ha}^{-1}$ in IPR Colibri and $10.05 \mathrm{~kg} \mathrm{ha}^{-1}$ in CNFC 15874) was the third nutrient most accumulated in grains of common bean in a grain yield of $2549 \mathrm{~kg} \mathrm{ha}^{-1}$ for IPR Colibri and 2.189 $\mathrm{kg} \mathrm{ha}^{-1}$ for CNFC 15874. Magnesium, Ca, S, Fe, Zn, $\mathrm{Mn}$ and $\mathrm{Cu}$ were the following order of nutrients accumulated by the grains.

Pegoraro et al. (2014) reported that using cultivar 'Pérola' the amount of nutrients exported by the grains was $93 \mathrm{~kg} \mathrm{ha}^{-1}$ of $\mathrm{K}, 82 \mathrm{~kg} \mathrm{ha}^{-1}$ of $\mathrm{N}, 34$ $\mathrm{kg} \mathrm{ha}^{-1}$ of $\mathrm{Ca}, 14 \mathrm{~kg} \mathrm{ha}^{-1}$ of $\mathrm{P}, 7 \mathrm{~kg} \mathrm{ha}{ }^{-1}$ of $\mathrm{S}$ and $6 \mathrm{~kg}$ $\mathrm{ha}^{-1}$ of $\mathrm{Mg}$, for a grain yield of $3.145 \mathrm{~kg} \mathrm{ha}^{-1}$. Soratto et al. (2013), with the same cultivar, observed nutrient exportation by common bean grains occurred in the following order: $\mathrm{N}>\mathrm{K}>\mathrm{P}>\mathrm{Ca}>\mathrm{S}>$ $\mathrm{Mg}$. Fageria et al. (2007) evaluating the effect of liming and nutrient uptake by common bean observed nutrient accumulations in the grains of $124 \mathrm{~kg} \mathrm{ha}^{-1}$ of $\mathrm{N}, 64 \mathrm{~kg} \mathrm{ha}^{-1}$ of K, $15 \mathrm{~kg} \mathrm{ha}^{-1}$ of $\mathrm{P} 9 \mathrm{Kg}$ $\mathrm{ha}^{-1}$ of $\mathrm{Ca}$ and $6 \mathrm{~kg} \mathrm{ha}^{-1}$ of $\mathrm{Mg}$ for the average yield of $3,409 \mathrm{~kg} \mathrm{ha}^{-1}$. For the production of one ton of grains of cv. Jalo EEP 558, cultivated under a conventional system in the Brazilian cerrado, Albuquerque et al. (2011) obtained the accumulation of $57.9 \mathrm{~kg}$ of N, $33.9 \mathrm{~kg}$ of K, $17.1 \mathrm{~kg}$ of $\mathrm{Ca}, 6.6 \mathrm{~kg}$ of $\mathrm{P}, 6.4 \mathrm{~kg}$ of $\mathrm{Mg}$ and $3.2 \mathrm{~kg}$ of $\mathrm{S}$ in the grains.

It is important to point out that $59.73 \%$ of $\mathrm{N}$ in the genotype CNFC 15874 and $57.97 \%$ of $\mathrm{N}$ in the genotype IPR Colibri was in the grains, $85.77 \%$ of $\mathrm{P}$ in the genotype CNFC 15874 and $66.84 \%$ in the genotype IPR Colibri was in the grains, and $74.58 \%$ of $\mathrm{Cu}$ in CNFC 15874 and $53.40 \%$ of $\mathrm{Cu}$ in IPR Colibri was in the grains.

Our data indicate that for grain producing even in a short cycle, such as the SEG of common 
bean, there is a consumption of all nutrients, for example, potassium extracts from the soil and exports by the grains in absolute value much more than $\mathrm{P}$ (Table 3). As higher the extraction per unit (ton) of grain produced as greater the requirement to produce. If it is extracted a lot and exports little, it indicates that there are enough nutrients in the straw for the following crops. Common beans, although extracting and exporting less $\mathrm{P}$ than $\mathrm{N}$ and $K$, it responds a lot to fertilization with $P$ because it has low absorption efficiency of $P$ (short cycle, poorly developed roots, etc.) (FAGERIA et al., 2011). Therefore, there is a greatest need for replacement of nutrients via fertilization in future systems recommendation, especially in view of the low availability of these nutrients in soils of tropical origin (SOUSA; LOBATO, 2004). High nutrient export rates by seeds in traditional cultivars were described by Fageria et al. (2007), where $90 \%$ of $P$, $88 \%$ of $\mathrm{N}$ and $61 \%$ of $\mathrm{K}$ were exported by grains from the growing area. Soratto et al. (2013) observed that more than $70 \%$ of $\mathrm{P}$, between 58 and $69 \%$ of $\mathrm{N}, 40$ and $52 \%$ of S, 40 and $48 \%$ of $\mathrm{K}$, and 35 and $45 \%$ of $\mathrm{Mg}$ absorbed during the cycle was exported with grains, whereas less than $15 \%$ of Ca was exported. Pegoraro et al. (2014) reported a percentage of exported $\mathrm{P}$ and $\mathrm{N}$ of the cultivation area was equivalent to 90 and $75 \%$, respectively of the total absorbed by common bean shoots. Data of the present research (short life cycle cultivars) and from other researches (traditional cultivars with long life cycle) showed that there are great amount of nutrients in the grains of common bean. In a fertilization program, total extraction, exportation of nutrients in the grains as well as nutrients uptake pattern, are important information used as parameters for fertilizing recommendation in cropping systems (FAGERIA et al., 2011; PAGANI; MALLARINO, 2012; CRUSCIOL et al., 2013).

\section{CONCLUSIONS}

Accumulation of nutrients by the shoots of super early genotype CNFC 15874 of common bean follows the decreasing order $\mathrm{N}>\mathrm{K}>\mathrm{Ca}>\mathrm{Mg}>\mathrm{P}>\mathrm{S}>$ $\mathrm{Fe}>\mathrm{Zn}>\mathrm{Mn}>\mathrm{Cu}$;

Nitrogen, $\mathrm{K}, \mathrm{P}, \mathrm{Mg}, \mathrm{Ca}, \mathrm{S}, \mathrm{Fe}, \mathrm{Zn}, \mathrm{Mn}$ and $\mathrm{Cu}$ was the order of accumulated nutrients in grains of super early genotypes of common bean;
Nitrogen, $\mathrm{P}$ and $\mathrm{Cu}$ was the nutrients with highest percentage in the grains of super-early genotypes of common bean;

Nutrients should be available to super-early genotypes of common bean between 14 and 21 DAS or around $\mathrm{V}_{4}$ stage.

\section{ACKNOWLEDGEMENT}

To the National Council for Scientific and Technological Development (CNPq) for the financial support (Process 471812/2013-7) and for an award for excellence in research of the first author.

\section{REFERENCES}

ALBUQUERQUE, A.; OLIVEIRA, D.P. ; VIEIRA, N.M.B.; ANDRADE, C.A.B.; ANDRADE, M.J.B. Partitioning of dry matter, nitrogen, phosphorus and potassium in bean genotypes. Annual Report of the Bean Improvement Cooperative, v. 54, n.1, p. 176-177, 2011.

ALVARES, C.L.; STAPE, J.L.; SENTELHAS, P.C.; GONCALVES, J.L.M.; SPAROVEK, G. Köppen's climate classification map of Brazil. Meteorologische Zeitschrift, v. 22, n.6, p.711-728, $2014 . \quad \quad$ https://doi.org/10.1127/09412948/2013/0507

ALVAREZ, R.C.F.; CRUSCIOL, C.A.C.; NASCENTE, A.S. Growth analysis and yield of traditional, intermediate and modern upland rice cultivars. Pesquisa Agropecuária Tropical, v.42, n.4, p.397406, 2012. https://doi.org/10.1590/S198340632012000400008

ANDRADE, C.A.B.; SCAPIM, C.A.; BRACCINI, A.L.; MARTORELLI, D.T. Yield, growth and common matter partition in two common bean cultivars. Acta Scientiarum Agronomy, v.31, n.4, p.683-688, 2009.

ARAÚJO, R. $\quad$ S.; RAVA, C.A.; STONE, L.F.; ZIMMERMANN, M.J.O. Cultura do feijoeiro comum no Brasil. Piracicaba: Associação Brasileira para Pesquisa de Potassa e do Fosfato, 1996.

AUGOSTINHO, L.M.D.; PRADO, R.M.; ROZANE, D.E.; FREITAS, N. Acúmulo de massa seca e marcha de absorção de nutrientes em mudas de goiabeira 'Pedro Sato'. Bragantia, v.67, n.3, p. 577-585, 2008. 
https://doi.org/10.1590/S0006$\underline{87052008000300004}$

BERGAMIN, A. C.; SCHLINDWEIN, J. A.; VENTUROSO, L.R.; VALADÃO JÚNIOR, D. D; CARON, B. O.; SCHMIDT, D. Resposta de duas cultivares de soja à adubação a lanço e em sulco, no município de Rolim de Moura/RO. Revista de Ciências Agrárias, v.50, n.1, p.155-166, 2008.

CONAB. Acompanhamento da safra brasileira: Grãos. Disponível em: <http://www.conab.gov.br/OlalaCMS/uploads/arq uivos/17_02_16_11_51_51_boletim_graos_feverei ro_2017.pdf>. Acesso em: 08 de fev. 2017.

CRUSCIOL, C.A.C.; NASCENTE, A.S.; SORATTO, R.P.; ROSOLEM, C.A. Upland rice growth and mineral nutrition as affected by cultivars and sulfur availability. Soil Science Society of America Journal, v.77, n.1, p.328-335, 2013. https://doi.org/10.2136/sssaj2012.0214

DONAGEMA, G.K.; CAMPOS, D.V.B.; CALDERANO, S.B.; TEIXEIRA, W.G. Manual de métodos de análise de solo. 2. ed. Rio de Janeiro: Embrapa Solos, 2011.

DOORENBOS, J.; PRUITT, W.O. Crop and water requirements. Roma: FAO, 1976.

EMBRAPA. Sistema brasileiro de classificação de solos. 2. ed. Rio de Janeiro: Embrapa Solos, 2006.

FAGERIA, N. K.; BALIGAR, V. C.; ZOBEL, R. W. Yield, nutrient uptake, and soil chemical properties as influenced by liming and Boron application in common bean in a no-tillage system. Communications in Soil Science and Plant Analysis, v.38, n. 11-12, p.1637-1653, 2007. https://doi.org/10.1080/0010362070138041 $\underline{3}$

FAGERIA, N.K.; BALIGAR, V.C.; JONES, C.A. Growth and mineral nutrition of field crops. 3. ed. Boca Raton: CRC Press, 2011.

FALQUETO, A.R.; CASSOL, D.; MAGALHÃES JÚNIOR, A.M.; OLIVEIRA, A.C.; BACARIN, M.C. Partição de assimilados em cultivares de arroz diferindo no potencial de produtividade de grãos. Bragantia, v.68, n.3, p.453-461, 2009.
https://doi.org/10.1590/S000687052009000300002

GOMES, A.A.; ARAÚJO, A.P.; ROSSIELLO, R.O.P.; PIMENTEL, C. Acumulação de biomassa, características fisiológicas e rendimento de grãos em cultivares de feijoeiro irrigado e sob sequeiro. Pesquisa Agropecuária Brasileira, v.35, n.10, p.1927-1937, 2000. https://doi.org/10.1590/S0100$\underline{204 \times 2000001000003}$

HAAG, H.P.; MALAVOLTA, E.; GARGANTINI, H.; BLANCO, H.G. Absorção de nutrientes pela cultura do feijoeiro. Bragantia, v.26, n.1, p.381-391, 1967. https://doi.org/10.1590/S0006$\underline{87051967000100030}$

LACERDA, M.C.; NASCENTE, A. S.; CARVALHO, M.C.S.; MONDO, V.H.V. Broadcast fertilizer rate impacts common bean grain yield in a no-tillage system. African Journal of Agricultural Research, v.10, n.14, p.1773-1779, 2015. https://doi.org/10.5897/AJAR2014.8525

LIMA, E.R.; SANTIAGO, A.S.; ARAÚJO, A.P.; TEIXEIRA, M.G. Effects of the size of sown seed on growth and yield of common bean cultivars of different seed sizes. Brazilian Journal of Plant Physiology, v.17, n.3, p.273-281, 2005. https://doi.org/10.1590/S1677-

$\underline{04202005000300001}$

MALAVOLTA, E.; VITTI, G.C.; OLIVEIRA, S.A. Avaliação do estado nutricional das plantas: princípios e aplicações. 2 ed. Piracicaba: POTAFOS, 1997.

NASCENTE, A. S.; KLUTHCOUSKI, J.; CRUSCIOL, C.A.C.; COBUCCI, T.; OLIVEIRA, P. Adubação de cultivares de feijoeiro comum em várzeas tropicais. Pesquisa Agropecuária Tropical, v. 42, n.4, p. 407$415, \quad 2012 . \quad$ https://doi.org/10.1590/S1983$\underline{40632012000400003}$

NASCENTE, A.S.; HEINEMANN, A.B.; ALVES, L. C.; ROSA, P. H.; NAVES, L.F.V.; GARCIA, A.C.F. Development of super early genotypes for the dry bean (Phaseolus vulgaris) as affected by nitrogen management. Australian Journal of Crop Science, 
v.10, n.8, p.1118-1126, 2016. https://doi.org/10.21475/ajcs.2016.10.08.p7596

NASCENTE, A.S.; MELO, L.C. Characterization of early genotypes of common bean. Annual Report of the Bean Improvement Cooperative, v.58, n.1, p.119-120, 2015.

PAGANI, A.; MALLARINO, A.P. Soil pH and crop grain yield as affected by the source and rate of lime. Soil Science Society of America Journal, v.76, n.5, p.1877-1886, 2012. https://doi.org/10.2136/sssaj2012.0119

PEGORARO, R.F.; OLIVEIRA, D.; MOREIRA, C.G.; KONDO, M.K.; PORTUGAL, A.F. Partição de biomassa e absorção de nutrientes pelo feijoeiro comum. Revista Caatinga, v.27, n.3, p.41-52, 2014.

ROSALES-SERNA, R.; KOHASHI-SHIBATAA, J.; ACOSTA-GALLEGOSB, J.A.; TREJO-LÓPEZA, C.; ORTIZ-CERECERES, J.; KELL, J.D. Biomass distribution, maturity acceleration and yield in drought-stressed common bean cultivars. Field Crops Research, v.85, n.2-3, p.203-211, 2004. https://doi.org/10.1016/S0378-4290(03)00161-8

SANTOS, L.A.; SORATTO, R.P.; FERNANDES, A.M.; GONSALES, J.R. Growth, physiological indices and yield of common bean cultivars under different levels of fertilization. Revista Ceres, v.62, n.1, p.107-116, 2015.

SAS Institute. Procedure guide for personal computers. Version 5. Cary. 1999. https://doi.org/10.1590/0034-737X201562010014
SORATTO, R.P.; FERNANDES, A.M.; SANTOS, L.A. ; JOB, A.L.G. Nutrient extraction and exportation by common bean cultivars under different fertilization levels: I macronutrients. Revista Brasileira de Ciência do Solo, v. 37, n.4, p.1027-1042, 2013. https://doi.org/10.1590/S0100-

06832013000400020

SOUSA, D.M.G.; LOBATO, E. Cerrado: correção do solo e adubação. 2. ed. Planaltina: Embrapa Cerrados, 2004.

VIEIRA, N.M.B.; ANDRADE, M.J.B.; CARVALHO, L.P.; REZENDE, P.M. Accumulation of macronutrients by different common bean cultivars grown in different plant densities in no-tillage crop system. Annual Report of the Bean Improvement Cooperative, v.52, n.1, p.132-133, 2009.

WIEN, H.C.; ALTSCHULER, S.L.; WALLACE, D.H. 14Cassimilate distribution in Phaseolus vulgaris $\mathrm{L}$. during the reproductive period. Journal of the American Society for Horticultural Science, v.101, n.1, p.510-513, 1976.

Recebido para publicação em 20/10/2017

Revisado em 27/03/2018

Aceito em 02/04/2018 